\title{
脊硬麻一私ならこうする一 硬膜外麻酔および春髄くも膜下麻酔に関する形態学的考察
}

\begin{abstract}
[要旨 $]$ 著者らは, 硬膜外注入および体位変換により脊韨・馬尾神経が形態学的にど のような影響を受けるか脊髄造影および MRI を用いて調べてきた．硬膜外に生理食 塩液を注入すると, くも膜下腔は硬膜外カテーテル先端近傍で強く圧迫された. また， 馬尾神経は側臥位および腹臥位になると，それぞれ重力方向に大きく偏位した．側卧 位で馬尾神経は中位腰椎レベルで最も大きく偏位し，上位および下位腰椎レベルでの 偏位は少ないものであった．脊髄くも膜下麻酔(脊麻)および硬膜外麻酔(硬麻)施行時 には，脊髄・馬尾神経に「動き」があることを考慮しなければならない，今回，脊麻 および硬麻に関連する资髄・馬尾神経の形態学的影響について考察した. キーワード：硬膜外麻酔, 脊髄くも膜下麻酔, 脊硬麻
\end{abstract}

(日臨麻会誌 Vol.24 No.9, $441 ４ 47,2004$ )

\section{はじめに}

硬膜外腔に薬液を注入すると, 硬膜囊は硬膜外腔 より圧迫され，くも膜下腔は予想以上に狭められる. 脊髄くも膜下麻酔(春麻) 施行後に硬膜外注入を行う と，脊麻の麻酔域が頭側に拡大するのは，おもにこ の現象に起因すると考えられている ${ }^{1)}{ }^{2)}$. 著者らは, 脊髄造影を用いた研究で，この現象の存在を明らか にした ${ }^{3)}$ 。そして今回, 硬膜外注入が脊髄くも膜下 腔に及ぼす形態学的影響を，春髄 MRIを用いてさら に詳細に調べた ${ }^{4}$ )。また，脊麻および硬膜外麻酔(硬 麻）は側臥位で施行されることが多いが，側臥位の 脊髄や馬尾神経に関する情報は皆無に等しい，そこ で，著者らは仰臥位，側臥位，腹臥位で脊髄MRIを 撮影し, 脊髄・馬尾神経の状態を観察した。仰臥位
でくも膜下腔内の背側に存在した脊髄・馬尾神経 は，側臥位および腹臥位になると，それぞれ重力方 向に，つまり左側臥位では左側 ${ }^{5)} に$ 腹臥位では腹側 に移動した。

このように硬膜外注入などの麻酔操作や患者の体 位変換により, 硬膜囊や馬尾神経に形態学的変化が 起きる。泰髄くも膜下硬膜外併用麻酔 (春硬麻) 施行 時の硬膜外注入，比重の異なる脊麻薬の麻酔効果の 違い, 馬尾症候群などの合併症などを考える場合, 硬膜および春髄・馬尾神経に「動き」があるなら，こ れを無視することはできない。これらは脊麻・硬麻 に関連した基本的で重要な事実であるにもかかわら ず，これまでほとんど論じられることがなかった。初 めて脊麻が施行されて 1 世紀以上も経過した現在，こ れらの基本的事実を再認識し, 脊麻・硬麻を形態学 


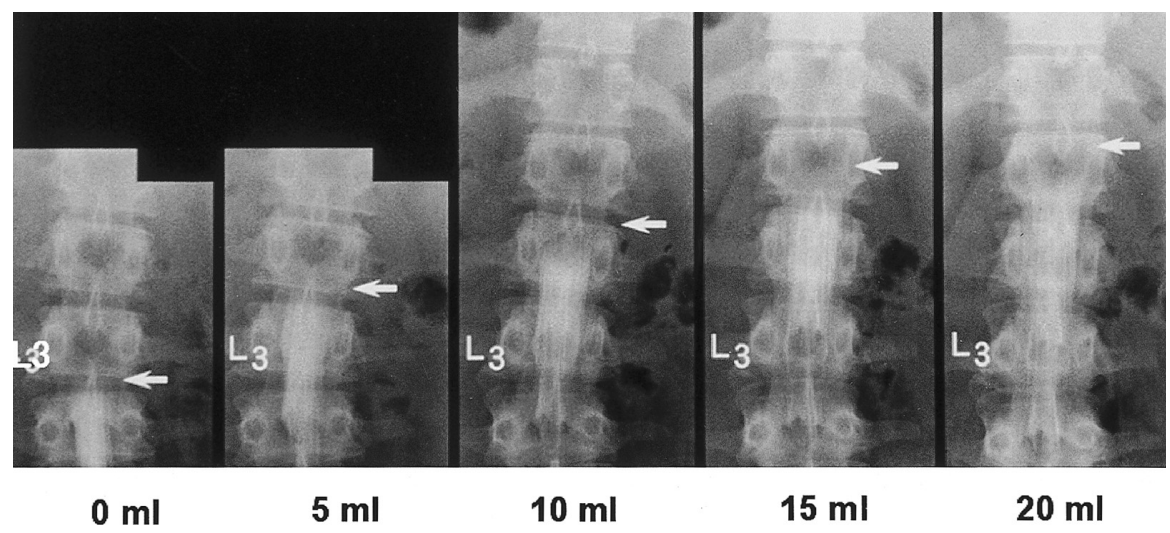

図 1 脊髄造影正面像

$(0 \mathrm{~m} l)$ ：造影剤注入直後で硬膜外生食注入前. $(5 \mathrm{~m} l)$ ：硬膜外カテーテルから生 食 $5 \mathrm{~m} l$ を注入した。 $(10 \mathrm{~m} l)$ ：同 $10 \mathrm{~m} l$ を注入。 $(15 \mathrm{~m} l)$ : 同 $15 \mathrm{~m} l$ を注入. $(20 \mathrm{~m} l)$ : 同 $20 \mathrm{~m} l$ を注入.

脊髄造影施行後に硬膜外カテーテルから生食を注入すると, くも膜下腔内の造 影剤が頭側に押し上げられた。 1 回に $5 \mathrm{~m} l$ ずつ注入したが, 注入回数が増すごと に造影剤上端の上昇幅は減じている (1回 $5 \mathrm{~m} l$ の硬膜外注入による造影剤上端の 頭側への移動距離が短くなる) [文献 3 ) より引用〕。

的立場からも見直す時期にきているのかもしれない.

\section{I 硬膜外注入で起こる形態学的変化}

脊麻後に硬膜外注入を行うと，即効性で強い麻酔 域の拡大が起こる．局所麻酔作用をもたない生理食 塩液(生食)を注入しても, 同じように麻酔域が拡大 する。これは，脊硬麻に独特の大変ユニークな現象 として知られるようになった容量効果である。春硬 麻ではこの容量効果を利用して，春麻の麻酔域を調 節することが可能である，例えば，下腹部手術なの に, 膝までしか脊麻が効いていない場合, 硬膜外に 生食を注入しただけで麻酔域が下腹部まで拡大す る. 局所麻酔薬(局麻)も使わず，麻酔法も変更せず に麻酔の維持ができる，局麻を使わない分，安全性 も高いと思われる。著者らは脊髄造影を用いた研究 で, 硬膜外注入によって硬膜囊が squeeze されて, くも膜下腔内の造影剤が頭側に押し上げられること を確認し，容量効果の存在を明らかにした ${ }^{3)}$. 図1 に脊髄造影研究の結果を示した。硬膜外カテーテル は L3/4 棘間から刺入し $5 \mathrm{~cm}$ 頭側に進めて固定し， 脊髄造影は L $4 / 5$ 棘間から施行し造影剂 $7 \mathrm{~m} l$ をくも
膜下腔に注入した。造影剂が頭側に流れないように 透視台を 45 度頭側挙上した状態で，硬膜外腔に生食 を 1 回 $5 \mathrm{~m} l$ ずつ 4 回注入した。造影剤の頭側への移 動は，初回の生食注入で最も大きく，注入回数が増 すごとに造影剤の上昇幅は減じている。このことは， 容量効果による脊麻の麻酔域の拡大には上限がある ことを示唆するものと考えられる。図2は側面像で あるが，硬膜外腔からの圧迫は左右方向より前後方 向に強く，〈も膜下腔は，後方硬膜外腔から腹側に 向けて圧迫され極端に狭められている，硬膜囊が歯 磨きのチューブを絞り出すように変形してその内容 を押し上げるこの現象を，著者は「歯磨きチューブ 効果」6) 8) と表現している。脊硬麻では, 脊麻単独で 施行する場合と比較して春麻の成功率が低いことが 指摘されている。このように極端に狭められたくも 膜下腔内に，脊麻針先端を留めおくことは難しい。 硬膜外注入によるくも膜下腔の高度な圧迫は，脊硬 麻時の脊麻の成功率を下げる原因の一つとして考え られるのではないだろうか.

硬膜外注入によって，〈も膜下腔が圧迫されるこ とはわかったが，その詳細はいまだ明らかでない。 


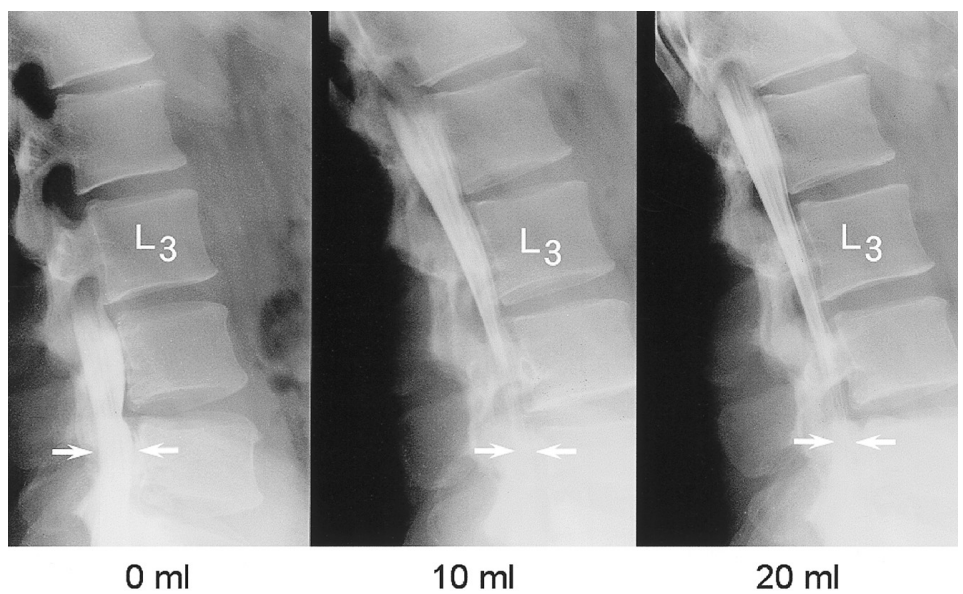

\section{図2 脊髄造影側面像}

$(0 \mathrm{~m} l)$ : 造影剤注入直後で硬膜外生食注入前. $(10 \mathrm{~m} l)$ : 硬膜外力 テーテルから生食 $10 \mathrm{~m} l$ 注入. $(20 \mathrm{~m} l)$ : 同 $20 \mathrm{~m} l$ を注入.

くも膜下腔は左右方向よりも前後方向に強く圧迫され, 特に L4/5棘間レベルでは極端に狭められている〔文献3）より引用】.

次に, 著者らはこの容量効果つまり硬膜外注入によ るくも膜下腔の圧迫の範囲や程度を, 健康成人男子 ボランティア 7 人でMRIを用いて調べた ${ }^{4)}$. 硬膜外 カテーテルは L $3 / 4$ から刺入し $5 \mathrm{~cm}$ 頭側に進めて留 置した. MRI は硬膜外カテーテル刺入レベル (L3/4) を基準点 $(0 \mathrm{~cm})$ として頭尾側方向に $1.5 \mathrm{~cm}$ 間隔の水 平断を硬膜外生食注入前後で撮影し，それぞれの水 平断面画像上でくも膜下腔の断面積を計測した。図 3 は硬膜外生食注入後のくも膜下腔断面積を注入前 のくも膜下腔断面積で除して圧縮率を算出したもの である. $10 \mathrm{~m} l$ の硬膜外注入によるくも膜下腔の有意 $(\mathrm{p}<0.05)$ な圧迫は, カテーテル刺入部 $(0 \mathrm{~cm})$ から 頭側に $10.5 \mathrm{~cm}$ ，尾側に $1.5 \mathrm{~cm}$ の範囲であった。 くも 膜下腔が強く $(\mathrm{p}<0.01)$ 圧迫されたのは, カテーテ ル刺入部から頭側に $3 \sim 9 \mathrm{~cm}$ のころで, 硬膜外力 テーテル先端近傍でやや頭側寄りであった。カテー テル先端から頭尾側に離れるに従って, くも膜下腔 への圧迫は漸減した. 反対に硬膜外腔に注目すると， くも膜下腔が圧迫されているところでは硬膜外腔が 拡大していることになる. 硬膜外腔へ注入した薬液 の広がりについては，2次元的には論じられてきた が3次元的に計測して調べたものはない. 硬膜外腔

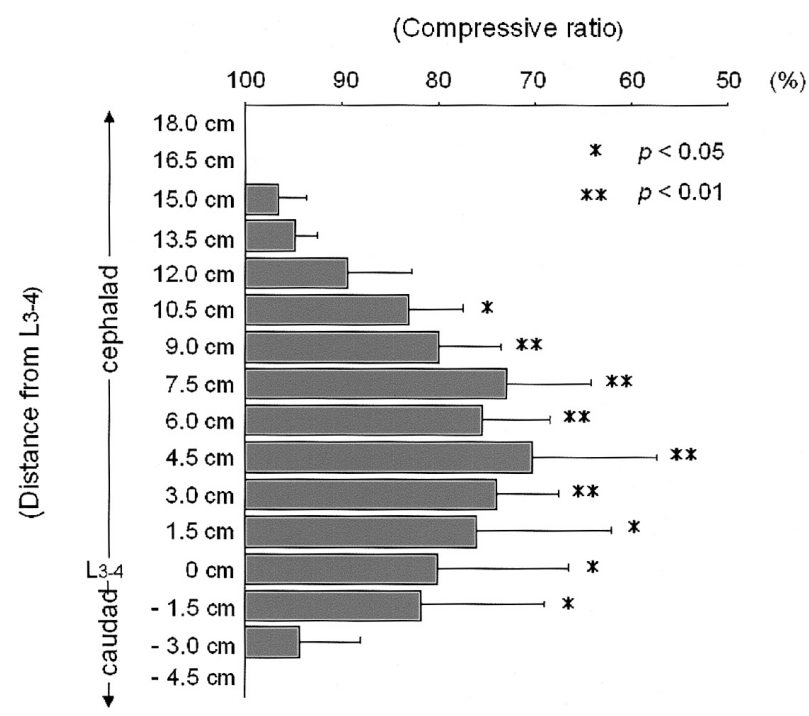

図3 硬膜外注入によるくも膜下腔の圧縮

硬膜外カテーテル刺入棘間(L3/4) レベルを $0 \mathrm{~cm}$ とし, そこから頭尾側方向にそれぞれ $1.5 \mathrm{~cm}$ 間隔の脊䯣 MRI 水平断面画像を, 硬膜外注入前後で撮像した。 各々の MRI画像から, $10 \mathrm{~m} l$ の硬膜外生食注入前後の くも膜下腔断面積を計測し, 注入後のくも膜下腔断 面積を注入前の断面積で除して各レベルでのくも膜 下腔の圧縮率 (compressive ratio) 算出した. カテー テル刺入高位 $(\mathrm{L} 3 / 4$ 棘間 $=0 \mathrm{~cm})$ から頭側に $3 \mathrm{~cm} \sim$ $9 \mathrm{~cm}$ の範囲でくも膜下腔の強い圧迫 $(\mathrm{p}<0.01)$ がみら れ， $4.5 \mathrm{~cm}$ のところが最大(注入前の約 $70 \%$ ) に圧迫 された。 


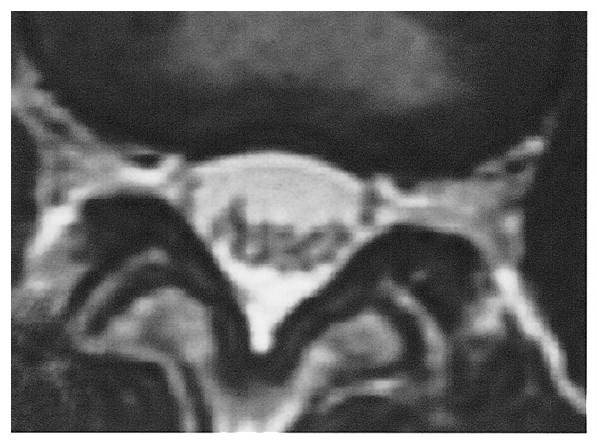

A

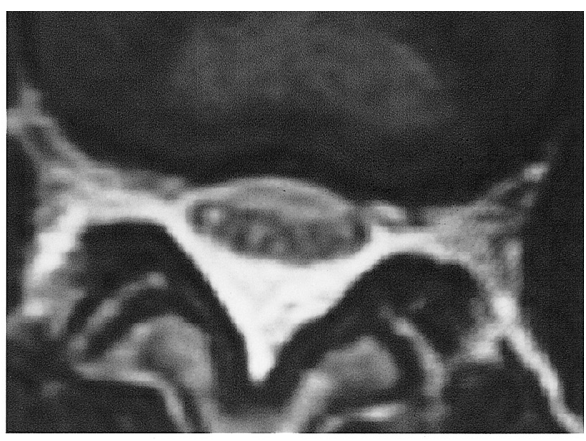

B

図4 MRI 水平断面画像

$\mathrm{A} ：$ 硬膜外生食注入前のくも膜下腔断面積は $166 \mathrm{~mm}^{2}$ であった.

B : $10 \mathrm{~m} l$ の硬膜外生食注入後には $86 \mathrm{~mm}^{2}$ となり, くも膜下腔断面積は注入前の 約 50 \%に圧縮された。この圧縮されたくも膜下腔内には，髄液はほとんど存 在しない. 生食注入後, 硬膜外腔は拡大している.

での広がりは，平面的なものではなく厚みがあるの である。この厚みは, 硬膜外麻酔の麻酔効果発現に 寄与することも推測される。厚いところ(カテーテ ル先端近傍でくも膜下腔への圧迫が強いところ)で は麻酔効果が強く, 薄いところ(注入部から離れた ところ)にいくと徐々に減弱するものと思われる. 今回の研究では, $10 \mathrm{~m} l$ の硬膜外注入を行ったが, カ テーテル先端近傍，つまり薬液が硬膜外に放出され る部位では少量の注入でも強い圧迫が起こることも 確認している．硬膜外カテーテルから薬液を注入す ると，速やかに薄く広がるのではなく，まずカテー テル先端近傍に溜まり，ある程度圧が高まると頭尾 側方向に流机出すようである。図4に, 硬膜外注入 前後の脊髄 MRIの 1 例を示す。硬膜外生食注入前の くも膜下腔断面積は $166 \mathrm{~mm}^{2}$ (図 4A) であったが, $10 \mathrm{~m} l$ の硬膜外生食注入によって $86 \mathrm{~mm}^{2}$ (図 4B) とな り, 約 $50 \%$ に圧縮された。この圧縮されたくも膜下 腔内の大部分が馬尾神経組織で占められ, 髄液はほ とんど存在しない.この状態でくも膜下腔穿刺を行っ た場合, 穿刺しても髄液の流出は起こるであろうか. くも膜下腔が穿刺されたとしても, 髄液流出がみら れず，いわゆるdry tap となることも考えられる。 今回の MRIの研究結果は, 脊硬麻時の脊麻の成功率
が低い原因の一つに容量効果によるくも膜下腔の狭 小化があることを支持するものではないだろうか. さらには，神経組織で満たされたくも膜下腔(図4B) に，脊麻針を刺入することを考えるなら馬尾神経損 傷の可能性も危惧される。抵抗消失法や test dose で 用いた量でも，注入部近傍ではくも膜下腔を強く圧 迫する可能性があり，特に同一棘間での硬膜外注入 直後のくも膜下腔穿刺には注意を要する，著者らは 容量効果を考慮して, 抵抗消失法で硬膜外腔へ注入 する生食は必要最小量(通常 $0.5 \mathrm{~m} l$ 以下) にしている.

硬膜外注入による容量効果は，脊麻施行後どれく らいまで脊麻に影響を与えるのであろうか。著者ら は, 容量効果による春麻の麻酔域の拡大は, 脊麻施 行後少なくとも 20 分までは起こりうることを報告し ている ${ }^{9)}$. 脊硬麻では脊麻施行直後の麻酔域が不足 しているからといって，すぐに硬膜外麻酔を追加す るのではなく容量効果を利用した脊麻の麻酔域の拡 大を図るべきである. $10 \mathrm{ml}$ の生食注入で $4 \sim 5$ 皮膚 分節の麻酔域の拡大が期待できる ${ }^{3)}$. 容量効果によ る麻酔域の拡大は即効性で, 数分で発現する，生食 を注入して 5 分から 10 分待って麻酔域が拡大しない のなら, 容量効果は発現しないものと判断し，それ から硬麻を追加(局麻薬の硬膜外注入)しても遅くは 
ない.

\section{II 体位の違いによる形態学的変化}

脊麻の際のくも膜下腔穿刺は側臥位, 坐位および 腹臥位で施行可能であるが，側臥位で施行されるこ とが多い. 図 5 は, 教科書にも示されている側臥位 でのくも膜下腔穿刺の概略図である。馬尾神経は, くも膜下腔背側に左右対象に整然と並んで描かれて いる。われわれは，このような形で与えられたくも

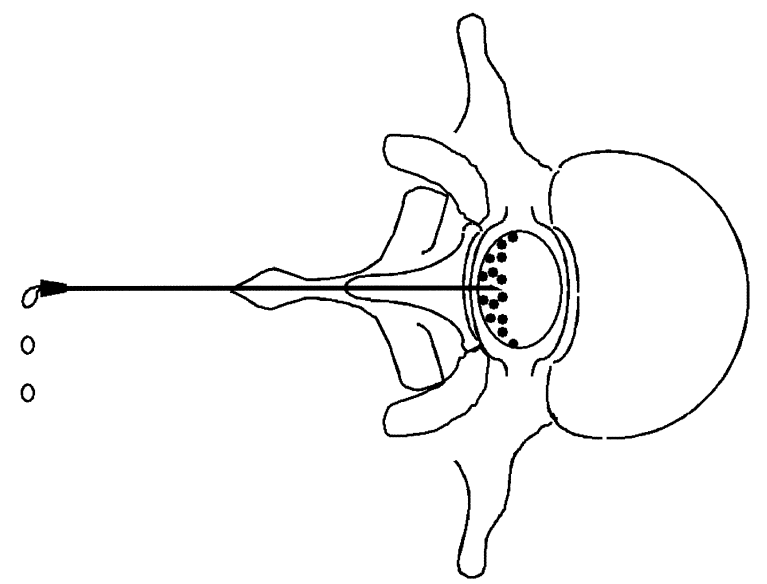

図5 側臥位のくも膜下腔穿刺の図

教科書でも示されている側臥位でのくも膜下腔穿刺 の概略図である。馬尾神経はくも膜下腔背側に左右 対象に整然と並んでいる.
膜下腔に関する情報を，疑うことなく受け入れてき た。事実，著者らも自ら撮影した側臥位の脊髄MRI 画像を目にするまで，図5で示されたような画像を イメージしてくも膜下腔穿刺を施行してきた。側臥 位での馬尾神経には，仰臥位と比べて形態学的にな んらかの違いがあるのであろうか. 著者らは健康成 人ボランティアを用いて，種々の体位で春髄 MRIを 施行し春髄および馬尾神経の状態を観察した。図6 は仰臥位と左側臥位の脊髄MRIである。仰臥位では, 馬尾神経はくも膜下腔内の背側に左右対象に位置し た(図6A)。側臥位で撮影した MRIをみると，馬尾 神経は重力方向に大きく偏位し (図6B) ${ }^{5}$ ，教科書に 示されている図5の状態とは異なるものとなった。 この事実から考えると，例えば重力側からの傍正中 接近法や正中から穿刺しても重力方向に針が進んだ 場合，神経密度の高い場所を穿刺することになる。 脊麻針刺入時や薬液注入時の電撃痛が馬尾症候群の 発症の危険因子で，その原因に脊麻が $55 \%$, 硬麻が $37 \%$ を占めるとの報告がある ${ }^{10), 11)}$ 。脊麻や脊髄造 影などのくも膜下腔穿刺を行う医療者は，患者体位 によって脊髄・馬尾神経の存在位置が移動すること を考慮すべきであろう。

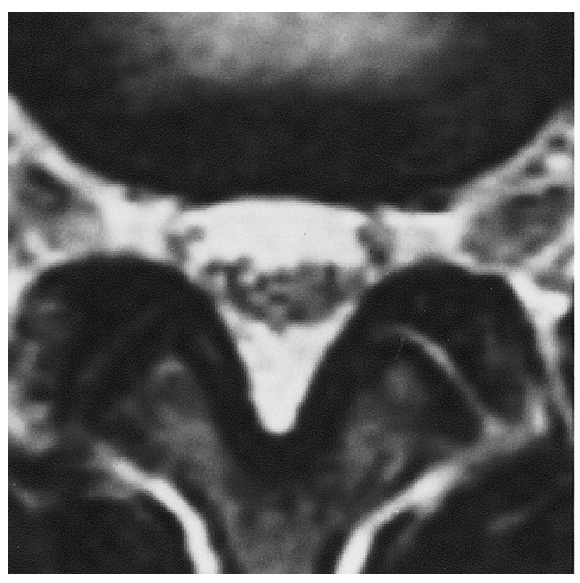

A

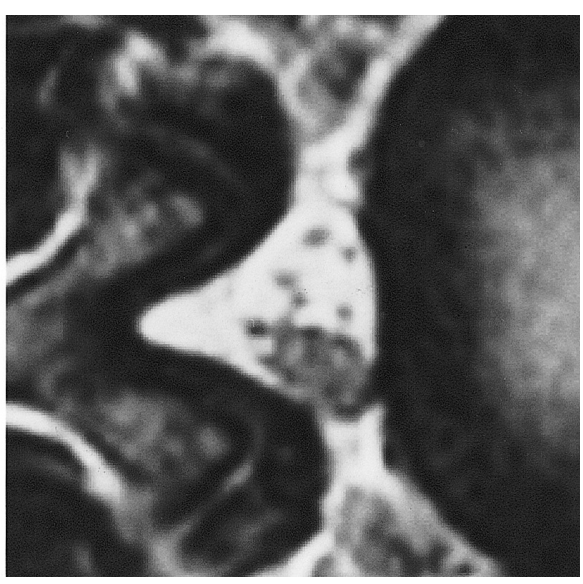

B

図6 体位変換による馬尾神経の動き (L2/3)

A : 仰臥位での馬尾神経はくも膜下腔内背側に左右対称に並んでいる.

$\mathrm{B}$ ：左側臥位になると，くも膜下腔内左側(重力方向)に大きく偏位した. 
また，脊麻には低(等) 比重と高比重局麻が使われ る. 局麻の比重の違いによる麻酔の効果の違いにつ いて論じた報告はあるが，その要因に体位による馬 尾神経の動きを考慮したものは見当たらない. 馬尾 神経の動きを考えると, 側臥位で注入したくも膜下 腔内の高比重液は, 図6Bのように重力方向に偏位 した馬尾神経に注がれることになる. 反対に, 低比 重液がくも膜下腔内で反重力方向に位置するなら, そこには馬尾神経組織はごく少数しか存在しない. さらに，著者らは腹臥位での馬尾神経が腹側に偏位 することも確認している，つまり，いずれの体位で も神経組織が重力方向に移動するために, 低比重液 は仰臥位，側臥位，腹臥位それぞれの体位で神経を 避けるように振舞うことになる。一般に, 側臥位で 施行した春麻においては, 低(等) 比重液に比べて高 比重液の方が，効果発現が早く麻酔の広がりがよい とされている ${ }^{12)}$ 15). その原因として著者は，この 体位の違いによる馬尾神経の動きが主役を演じてい るものと考えている.

\section{まとめ}

これまで, 硬膜外注入などの麻酔操作や患者体位 の変換によって脊髄・馬尾神経が形態学的に変化す ることが指摘されることは少なく，われわれ麻酔科 医もこのことをあまり意識することがなかった．著 者らは，硬麻および春麻と硬膜・脊髄・馬尾神経の 形態学的関係には以前より注目してきた。今回の研 究では, くも膜下腔の面積変化から, 硬膜外注入の 広がりと厚みを計測し, 容量効果をより明確なもの にした，さらに，MRIを用いて種々の体位による馬 尾神経の動きを観察し，側臥位をとると馬尾神経は 重力方向(下にした方)に偏位することを確認した。 側臥位での馬尾神経は中位腰椎高位で最も大きく重 力方向に偏位し, それより頭側(胸椎方向), および 尾側(仙骨方向)にいくに従って偏位は少ない。つま り, 馬尾神経が下部胸髄と仙尾骨の間に紐を垂らし たような状態となり，これが，あたかも街角の電柱
に張られた電線のごとくであることから，著者は側 臥位でのこの現象を「馬尾神経の電線現象」と名づ けて呼んでいる。

春麻，硬麻，および脊硬麻施行時には，体位変換 や麻酔操作による硬膜囊・脊髄・馬尾神経の形態学 的変化を考慮しなくてはならない.

\section{参考文献}

1) Cook TM : Combined spinal-epidural techniques. Anaesthesia $55: 42 \sim 64,2000$

2) Liu SS, McDonald SB : Current issues in spinal anesthesia. Anesthesiology $94: 888 \sim 906,2001$

3) Takiguchi $T$, Okano $T$, Egawa $H$, et al. : The effect of epidural saline injection on analgesic level during combined spinal and epidural anesthesia assessed clinically and myelographically. Anesth Analg 85 : 1097 1100, 1997

4）滝口鉄郎：脊硬麻一私ならこうする一「作用様式と私 の手法」. 日臨麻会誌 $23 ：$ S213, 2003

5) Takiguchi T, Yamaguchi S, Okuda Y, et al. : Deviation of the cauda equina by changing position. Anesthesiology $100: 754 \sim 755,2004$

6）滝口鉄郎：脊椎硬膜外麻酔のメカニズム。臨床麻酔 $22: 971 \sim 980,1998$

7）滝口鉄郎：水で麻酔がかけられる!?一歯磨きチューブ効 果と脊椎硬膜外麻酔の使い方一麻酔 - 救急 - 集中治療 専門医の極意. 具沼関志編. 真興交易医書出版部, 東 京, 2001，36 50

8) 高崎眞弓 : 脊硬麻 (脊䯣くも膜下麻酔と硬膜外麻酔の併 用)，こだわりの局所麻酔、メディカル・サイエンス・ インターナショナル，東京， 2002，123〜 138

9）加瀬幸子, 小林俊哉, 滝口鉄郎ほか：硬脊麻時の麻酔 高に関する硬膜外生理食塩水注入の容量効果について. 麻酔 $47 ： 1080 \sim 1084,1998$

10) Auroy Y, Narchi P, Messiah A, et al. : Serious complications related to regional anesthesia : results of a prospective survey in France. Anesthesiology $87: 479$ 486, 1997

11) Cheney FW, Domino KB, Caplan RA, et al. : Nerve injury associated with anesthesia : a closed claims analysis. Anesthesiology $90: 1062 \sim 1069,1999$

12) Chambers WA, Edstrom HH, Scott DB : Effect of baricity on spinal anaesthesia with bupivacaine. $\mathrm{Br} \mathrm{J}$ Anaesth $53: 279 \sim 282,1981$

13) Phelan DM, MacEvilly M : A comparison of hyperand isobaric solutions of bupivacaine for subarachnoid 
block. Anaesth Intensive Care $12: 101 \sim 107,1984$

14) Sanderson P, Read J, Littlewood DG, et al. : Interaction between baricity (glucose concentration) and other factors influencing intrathecal drug spread. Br J Anaesth $73: 744 \sim 746,1994$
15）鈴木太，小川節郎，花岡一雄ほか：脊椎麻酔における $\mathrm{AJ}-007$ (塩酸ブピバカイン) の臨床試験一等比重および 高比重製剂の臨床用量の検討一. 麻酔 47 : 447〜 465, 1998

\title{
Morphological Investigation for Epidural or Spinal Anesthesia
}

\author{
Tetsuo TAKIGUCHI
}

Department of Anesthesiology, Dokkyo University School of Medicine

In the present review, the author described some important information regarding epidural, spinal, or combined spinal and epidural anesthesia (CSEA). The author has demonstrated that the cephalad spread of the contrast medium in the subarachnoid space, and the compression of the subarachnoid space are observed after epidural injection of physiological saline solution using myelography and magnetic resonance imaging (MRI). These studies suggest the volume effect during CSEA. Furthermore, the author reported that the cauda equina moved to the gravity-dependent side, when changing from the supine to the lateral decubitus or prone position. These results differ from the previous studies, so that it is necessary for us to guard against movement of the cauda equina when we perform the spinal anesthesia.

Key Words : Epidural anesthesia, Spinal anesthesia, Combined spinal and epidural anesthesia 